\title{
Frazemi s pomenom 'piti' in 'biti pijan' v slovenskem in ruskem jeziku
}

\author{
Elena Savelieva
}

IZVLEČEK: V prispevku ima avtorica namen prikazati, kako se prekrivata in razlikujeta frazeologiji slovenskega in ruskega jezika pri izražanju pijančevanja oz. pijanosti, ki sta $v$ obeh jezikih predstavljena $z$ bogato paleto frazemov.

ABSTRACT: The author intends to show the overlapping and the differences between Slovene and Russian phraseology for drinking and drunkenness. There is a wide variety of phrasemes covering this topic in both languages.

\section{Uvod}

Kontrastivne primerjave frazeologije različnih jezikov so pokazale, da pogostokrat $\mathrm{v}$ frazeološkem sestavu dveh ali več jezikov prihaja do podobnosti. Le-te se kažejo predvsem $\mathrm{v}$ procesih frazeologizacije in izkazujejo nekatere univerzalne zakonitosti (Jesenšek 2000, 242-243). Že Solodub (1982, 108), ki se je ukvarjal z vprašanjem tipološkega ujemanja frazeoloških enot v različnih jezikih, je omenjal dva dejavnika, ki prispevata $\mathrm{k}$ podobnim načinom izražanja situacij $\mathrm{v}$ frazemih: (1) skupne življenjske izkušnje, podobni logični in asociativni procesi mišljenja ter videnje sveta, tudi pri takih narodih, ki nimajo nobenih jezikovnih stikov; (2) tesni zgodovinski stiki med posameznimi narodi. Drugi dejavnik povzroča, da se lahko zbližajo frazeološki sistemi jezikov, ki niso sorodni. ${ }^{1} \mathrm{~V}$ evropskem kulturnem prostoru bo visoka stopnja ujemanja pri frazemih, ki segajo $\mathrm{v}$ tradicijo antike in krščanstva. Tesni stiki med posameznimi narodi pa lahko privedejo do prevzemanja frazemov. Toda pri prevzemanju in kalkiranju jezik iz drugojezičnega poimenovanja ne sprejme samo oblikovno in strukturno, temveč tudi pojmovno podobo, s katero se strinja, saj drugače ne bi prišlo do prevzemanja (Jesenšek 2000, 243). Glede na to, da ruščina in’slovenščina nista bili v tesnem

1 Treba je opozoriti na medjezikovno frazeološko homonimijo, ko pomeni frazemov ne sovpadajo, čeprav imajo isto strukturo, npr. ruski frazem iz koži von lezt' pomeni 'prizadevati si', medtem ko nemški frazem aus der Haut fahren pomeni 'razjeziti se', tako tudi slovenski frazem skočiti iz kože. 
stiku kot na primer slovenski in nemški jezik, lahko pri primerjavi ruskih in slovenskih frazemov izhajamo iz prve točke, kot jo navaja Solodub. V obeh jezikih lahko pride do podobnosti pri frazemih na podlagi podobnih življenjskih izkušenj, podobnega načina mišljenja in dojemanja. Predstavniki kognitivnega jezikoslovja trdijo, da človek dojema svet in ga oblikuje metaforično, s pomočjo podob. To se kaže tudi v frazeologiji. Frazemi so pretežno motivirane enote, v svoji notranji zgradbi imajo podobo. Ta se oblikuje iz pomenov prvotnih besed, ki so v sestavu frazema, šele potem te besede dobijo nov pomen, pri tem pa pustijo sled prvotnega pomena v podobi (Čerdanceva 1996, 64). Povezanost pomena in podobe je lahko eksplicitna ali implicitna. $V$ primeru slednjega je treba poseči v zgodovinski razvoj frazema, da bi ugotovili prvotno situacijo, na podlagi katere je prišlo do njegovega nastanka. Nemalokrat je bilo poudarjeno, da je frazeologija načelno usmerjena $v$ človeka, frazemi prvotno nastajajo, da bi interpretirali svet, izražali subjektiven in čustveno obarvan odnos govorca do sveta (Dobrovol'ski, Karaulov 1993). Večje število frazemov $v$ jeziku za označevanje določenih pojavov, dejanj, lastnosti priča o tem, da se človek najbolj zanima zanje, srečuje se z njimi vsak dan in jih doživlja. Povsem logično je, da bo negativno vrednotenje v frazeologiji imelo najobsežnejše skupine. Ena izmed takih je pijančevanje. Naša naloga je predvsem primerjalno prikazati, kako se pijanost frazeološko izraža $\mathrm{v}$ slovenskem in ruskem jeziku in katere podobe se najpogosteje pojavljajo $\mathrm{v}$ obeh jezikih.

\section{Frazemi, ki ubesedujejo pijančevanje in pijanost}

V Slovarju slovenskega knjižnega jezika $(1998,840,1515)$ najdemo naslednjo razlago besed pijan oz. vinjen: pijan '1. ki zaradi zaužite alkoholne pijače ne govori, ne ravna normalno, razsodno // ki izraža, kaže tako stanje'; vinjen 'ki se mu zaradi zaužite alkoholne pijače zmanjša sposobnost normalnega, razsodnega mišljenja, ravnanja'. ${ }^{2}$ Vse razlage slovarja so potrjene tudi v frazemih, npr. jezik se komu zapleta, pijan, da samega sebe vika, piti kot goba itd. Glagole, ki v slovenskem jeziku pomenijo 'piti alkoholne pijače', je zbral Janez Keber (1992, 109): izpijati, pijančevati, pijaniti, pijuckati, cediti, črepati, cuzati, lokati, luckati, nategovati, nažehtati se, pokušati, pokusiti, pupati, pupcati, srebati, srebrniti, tankati, zamakati, zvračati, žlampati. Temu seznamu bi še lahko dodati glagole: nabrenkati se, nacehati se, nacukati se, nagostiti se, nakresati se, nasekati se, nasrkati se, natakati se, natreskati se, natrkati se, navleči se, nažlampati se, nažreti, zaliti se ter bandati, cehati, lumpati.

Številne frazeme, ki poimenujejo dejanje 'piti', stanje 'pijan' in posledice pitja $v$ obeh jezikih, se da pomensko razdeliti v tri večje skupine. Prva in druga skupina bosta imeli še podpomene glede na intenzivnost. ${ }^{3}$

2 Treba je omeniti, da slovarska razlaga ne daje določenih razlik med besedama pijan in vinjen. Ne glede na to so bili frazemi, ki so imeli v svoji razlagi besedo vinjen, uvrščeni v skupine s pomenom 'nekoliko pijan', ker se razlika kaže npr. v ponazarjalnem primeru bil je vinjen, ne pa pijan, ki ga najdemo v geslu vinjen.

3 Glede na to, da je ruska frazeologija precej raziskana in je dosegljiva v slovarjih, navajamo samo slovenske frazeme. Enojna poševnica loči variante, dvojna pa glagolski vid. V 


\subsection{Pitje alkohola glede na kolicino in pogostnost:}

2.1.1 občasno malo piti oz. popiti malo alkoholne pijače:

pogledati v kozarec (ekspr.), močiti grlo//namočiti si grlo (ekspr.), kdo rad lok lok/luk luk (šalj.), dati ga na zob (pog., ekspr.), rukniti ga (pog., ekspr.), suniti ga (pog., ekspr.);

2.1.2 občasno se predajati pijančevanju:

(pridno) gledati v kozarec (ekspr.), globoko gledati//pogledati $v$ kozarec (šalj.), segati po steklenici (ekspr.), (pridno) prazniti/izpraznjevati kozarce (ekspr.), (pridno) nagibati kozarce (ekspr.), (vztrajno) objemati kozarec (ekspr.), ovijati kozarec/steklenico (ekspr.), ne braniti se kozarca (ekspr.), sedeti pri majoliki (ekspr.), sušiti vino (ekspr.), ladjice potapljati, piti ga (pog., ekspr.), cukati ga (ekspr.), polokati//lokati ga (pog.), luckati ga (pog., ekspr.), pokončati ga (̌̌alj.), srebati// srebniti ga (pog., ekspr.), srkati//srkniti ga, (posrkniti ga) (pog., ekspr.), usušiti ga (ekspr.), vleči ga (pog.), zdelati ga (pog., ekspr.), zvračati ga (pog., ekspr.), žehtati ga (slabš.), žreti ga (pog.);

2.1.3 zelo, veliko piti:

piti kot (božja) mavra (ekspr.), piti kot krava (pog., ekspr.), piti kot žaba (ekspr.), piti kot žolna (ekspr.), piti kot živina, piti kot goba, piti ko lij, piti na mrtvo/na žive in mrtve (ekspr.), piti skozi rokav in ne skozi grlo, natakati se/nalivati se $z$ vinom (ekspr.), piti, kot bi v jamo zlival, imeti gobe v želodcu (ekspr.);

2.1.4 popolnoma se predati alkoholu:

utopiti se $v$ vinu, vdati se pijači.

\subsection{Pijanost (stanje pijanega človeka) glede na stopnjo:}

2.2.1 biti nekoliko pijan:

biti pod gasom (nižje pog., ekspr.), biti pod paro (pog.), biti v rožicah (pog., ekspr.), imeti ga pod kapo (pog., ekspr.), imeti ga pod klobukom (pog.), imeti ga pod streho (pog., ekspr.), (malo) ga imeti v glavi (pog., ekspr.), imeti muho, biti mehak, biti korajžen, imeti ga (pog., ekspr.), čutiti ga (pog., ekspr.);

2.2.2 biti zelo, močno pijan:

pijan kakor/kot kmečka nevesta, pijan kakor/kot metla, pijan kot muha (ekspr.), biti nadelan kot muha, biti nadelan do mrtvega, pijan kot čep (pog.), pijan kot klada, pijan kot veha, pijan kot žolna, pijan kot batina, pijan kot krava (pog., ekspr.), pijan kot (božja) mavra (ekspr.), pijan kot prasec, pijan kot svinja (vulg.), pijan/natreskan kot kanon, na smrt pijan (ekspr.), pijan kot bi bil ubit, pijan kot dež, pijan v pilko (nar.), pijan do nezavesti (ekspr.), biti potrjen (žarg.), biti trd, dobiti ga v glavo, nabrati se ga kakor berač mraza (pog.), nabrenkati se ga (pog.), nacediti se ga (pog., ekspr.), nacukati se ga (pog., ekspr.), nakresati se ga (pog.), nalesti se ga, nalokati se ga (pog.), naložiti se ga (pog., ekspr.), naluckati se ga (pog., ekspr.),

okroglem oklepaju so fakultativne sestavine. Nekateri frazemi imajo stilne oznake, povzete po SSKJ. Za vir so služili Slovar slovenskega knjižnega jezika (1998), Slovenski pravopis (1962), Pleteršnikov slovensko-nemški slovar (1894/95) in razprave posameznih avtorjev. Ruske frazeme gl. v Birih, Mokienko, Stepanova (2001), gesla НАПИВАТЬСЯ/ НАПИТЬСЯ (ПИТЬ), ПЬЯНСТВОВАТЬ, ПЬЯНЫЙ. 
nasekati se ga (pog., ekspr.), natreskati se ga, natrkati se ga (pog., ekspr.), nazobati se ga (pog., ekspr.), napiti se ga (pog.), nasrkati se ga (pog., ekspr.), nažehtati se ga (pog., slabš.), nažreti se ga (nizko, pog.), napiti se do mrtvega (ekspr.);

2.2.3 biti tako pijan, da se ne zaveda svojega početja:

pijan, da samega sebe vika; pijan, da mački pravi botra (ekspr.); pijan, da bi žabe vikal (ekspr.); pijan, da ne loči meseca od sonca; pijan, da ne ve zase.

\subsection{Posledice pitja alkohola (fizične in psihične):}

2.3.1 biti pijan do halucinacij: videti bele miši;

2.3.2 imeti težave $\mathrm{z}$ govorom: jezik se komu feclja;

2.3.3 imeti težave z obvladanjem telesa:

biti tako pijan, da še $z$ enim prstom ne more migniti; biti opletav (ekspr.); biti mehak; meriti cesto (ekspr.); voziti barko 'pijan se opotekati iz krčme v krčmo', razkazovati opico;

2.3.4 imeti glavobol od pijanosti: imeti mačka, imeti opico.

\section{Analiza frazemov}

3.1 Na podlagi primerjanega gradiva se da $v$ jezikih glede na pomensko, motivacijsko in oblikovno raven določiti štiri skupine frazemov:

(2) frazemi, ki so $\mathrm{v}$ obeh jezikih identični na pomenski, motivacijski (podoba) in oblikovni ravni: piti kot goba - пить как (грецкая) губка, pijan kot klada - Пьян как колода, пьян как чурбан, pijan kot svinja - пьян как свинья;

(3) frazemi, ki so identični v pomenu in podobi, razlikujejo se v obliki: gledati/ /pogledati v kozarec - заглядывать в рюмку, тос̌iti grlo//namočiti si grlo - промочить горло, biti pod paro - под парами, biti pod gasom - под газом, biti korajžen - под куражом, в кураже, napiti se do mrtvega напиваться//напиться в усмерть, пьян в усмерть, pijan kot bi bil ubit, na smrt pijan - мертвецки пьян, pijan do nezavesti - напиваться/напиться до потери сознания;

(4) frazemi, ki imajo identičen pomen in obliko, razlikujejo se v podobi: pijan kot prasec - Пьян как свинья, пьян как зюзя, pijan kot batina - пьян как колода, как чурбан, piti kot živina, kot krava, kot žolna, kot žaba - пить как лошадь;

(5) frazemi, ki so identični v pomenu, razlikujejo se na motivacijski in oblikovni ravni. Sem spadajo vsi drugi frazemi, npr. slovenski sušiti vino, sedeti pri majoliki, ladjice potapljati, imeti gobe $v$ želodcu, imeti ga pod kapo, voziti barko, razkazovati opico; ruski frazemi наливать//налить бельмы, заливать/ /залить глаза вином, заливать//залить шары, пить горькую/мертвую, напиваться//напиться в дрызг, в дупель, в дребь, совершать//совершить возлияние itd. 
Do razlik med jezikoma na strukturni ravni prihaja predvsem zaradi različnih načinov izražanja predikacije. Slovenščina uporablja pomožni glagol biti, česar ruščina nima $\mathrm{v}$ svoji skladnji, npr. frazemi biti pod paro, biti pod gasom, biti $v$ rožicah, biti trd. Med slovenskimi frazemi je veliko primerov s strukturo glagol + osebni zaimek. Tovrstni frazemi so značilni za slovenski jezik. Osebni zaimek ga je »prikrito« poimenovanje alkohola. Pri obravnavi frazemov s to strukturo je Kržišnikova postavila še vedno aktualno vprašanje: ali gre za frazeme ali za besede s prostim morfemom (Kržišnik 2001, 248). Osebni zaimek ga se pojavi tudi v frazemih imeti ga pod kapo/pod klobukom/pod streho in v primerih naložiti se ga, naluckati se ga, nasekati se ga itd. Oba jezika izražata skrajno mero s predlogom do (do nezavesti, do mrtvega; до упора, до бесчувствия), poleg tega ima slovenščina primere s predlogom na (na žive in mrtve), ruščina pa s predlogom $v$ (в усмерть, в доску). Razliko med jezikoma je opaziti tudi v obliki primerjalnih frazemov. Oba jezika imata namreč frazeme z obliko glagol/pridevnik (piti/pijan) + kot/kakor + samostalniška beseda ali besedna zveza. Slovenščina ima poleg tega frazeme z obliko glagol/pridevnik + (kot) + stavek (npr. pijan, da samega sebe vika; piti, kot bi v jamo zlival; pijan, kot bi bil ubit).

3.2 Že s površnim pogledom na zbir frazemov, ki poimenujejo pijančevanje, lahko ugotovimo, da so zelo različni z oblikovnega in motivacijskega vidika. Pozornost bo posvečena frazemom s pomenom piti in biti pijan. V obeh jezikih predvsem izstopajo primeri, ki imajo v svojem sestavu predmetna poimenovanja, npr. kozarec, klada, goba in poimenovanja živali, npr. krava, konj, svinja itd. V ruščini tvorijo obsežno skupino frazemi, ki imajo za sestavino poimenovanje poklicev, npr. пьяный как грузчик/дворник/извозчик/лакей/пожарник'pijan kot nakladač, hišnik, kočijaž, lakaj, gasilec', пить, напиваться//напиться как сапожник, пить как мастер портной, как старый морской волк 'piti, napiti se kot čevljar, krojač, star, izkušen mornar'. Podobnih frazemov s pomenom 'piti' ali 'biti pijan' slovenščina nima.

\subsubsection{Frazemi s sestavino, ki poimenuje predmet ${ }^{4}$.}

3.2.1.1 Med poimenovanji predmetov, ki nastopajo $\mathrm{v}$ frazemih, izstopajo predvsem tisti, ki spadajo v pomensko polje 'posoda', npr. kozarec, steklenica, majolika, lij idr. Poimenujejo dejanje 'piti', ki je prikazano s pomočjo situacij: premikanje, dotikanje posode za pijačo ali nahajanje blizu le-te, npr. slovenski frazemi (pridno) gledati//pogledati $v$ kozarec, segati po steklenici, ne braniti se kozarca, prazniti//izpraznjevati kozarce, (pridno) nagibati kozarec, (vztrajno) objemati kozarec, ovijati kozarec/steklenico, sedeti pri majoliki in ruski заглядывать в рюмку (рюмочку)/ в бутылку 'pogledati v steklenico', прикладываться// приложиться к бутылке 'dotikati se steklenice', пропускать по рюмочке /по маленькой 'spustiti po kozarčku, malem' (metonimično izražanje kozarčka vina)/ стаканчик (по стаканчику), хлопнуть по маленькой, нырнуть по маленькому

4 Beseda predmet se uporablja v drugem slovarskem pomenu 'kar je izdelano, narejeno za zadovoljevanje določenih potreb, opravljanje določene dejavnosti'. 
'izpiti na dušek po malem', in frazem придерживаться рюмочки/стаканчика 'držati se kozarčka'. ${ }^{5}$ Do razlik med jezikoma prihaja na pomenski ravni. Slovenski frazemi označujejo občasno pitje alkohola $v$ velikih količinah, ruski pa razen zadnjega, ki ima pomen 'stalno piti', poimenujejo občasno pitje, popivanje $\mathrm{v}$ malih količinah, kar se vidi tudi iz manjšalne oblike besed kozarec in steklenica. Poleg navedenih frazemov sta še dva, ki gradita na različnih podobah, in sicer slovenski frazem sedeti pri majoliki in ruski раздавить бутылку ('poteptati steklenico'), ter še primerjalna frazema, ki imata v svojem sestavu besede, ki so nekako v zvezi s pijačo: slovenski frazem piti kot lij in ruski пить как (бездонная) бочка (dobesedno 'piti kot sod brez dna'). V slovenskih frazemih, ki prikazujejo stanje pijanosti, nastopajo tudi poimenovanja predmetov za mašenje posod za vino: biti natreskan kot čep, pijan kot čep/kot veha, pijan v pilko. Po Kebru je prišel čep v primero zaradi svoje vloge pri sodu, $v$ katerem se nahaja pijača. Enako velja za pilko, ki v bizeljskem narečju pomeni 'čep', in veho (Keber 2003, 33). Ruskojezičnemu govorcu čep ne bo asociiral pijanosti, temveč neumnost, kar se kaže iz frazema глуп как пробка.

3.2.1.2 Stanje pijanosti se primerja tudi z neprožnimi predmeti, ki so omahljivi v navpičnem stanju, npr. pijan kot metla/kot klada/kot batina, пьян как чурбан, пьян как колода. Morda tudi primerjava s kanonom v frazemu pijan/natreskan kot kanon gradi na isti podobi omahljivosti. Ruski frazemi пьян как стелька, пян в стельку, напиваться//напиться как стелька imajo v svojem sestavu besedo podplat, torej biti tako pijan, da leži kot podplat. Isto podobo ležečega stanja ima frazem напиваться//напиться в доску 'napiti se kot deska'.

3.2.1.3 V frazemih nastopajo še druga poimenovanja predmetov. $\mathrm{V}$ obeh jezikih veliko količino pitja med drugim izraža primerjava z gobo 'prožen luknjičast predmet, ki vpija vodo': piti kot goba, пить как грецкая губка. Za razliko od slovenščine se $\mathrm{v}$ ruščini z gobo ne primerja le pitje, ampak tudi stanje pijanosti пьян как грецкая губка. V Pleteršnikovem Slovensko-nemškem slovarju v geslu pijan najdemo primer biti pijana goba, v geslu goba pa imeti gobo $v$ želodcu, ki je prisoten tudi v nemščini einen Schwamm in Magen haben. V ruščini se v frazemih pojavljajo še deli oblačil kot галстук in воротник: закладывать//заложить за галстук/за воротник, kar dobesedno pomeni 'polagati za kravato, ovratnik'. Stanje pijanosti se v ruščini primerja tudi z dežnikom: напился (напиться) как зонтик 'napil se je kot dežnik', ki je mogoče nastal iz dejstva, da se blago dežnika pod močnim dežjem zelo namoči. Samo za slovenski jezik so značilni naslednji primeri, $\mathrm{v}$ katerih se kot sestavina pojavljajo predmeti: imeti ga pod kapo/pod klobukom/ pod streho. Frazemi poimenujejo stanje opijanjenja.

\subsubsection{Frazemi s poimenovanjem živali}

$\mathrm{V}$ obeh jezikih se čezmerno pitje in stanje opijanjenja največkrat primerja $\mathrm{z}$ živalmi, npr. piti, pijan kot (božja) mavra/kot krava/kot žolna, piti kot žaba/kot

5 Podobne frazeme najdemo tudi v nemščini gern ins Glas gucken, zu tief ins Glas gucken ali zu tief in die Kanne gucken, zur Flasche greifen, dem Glas(e) (fleißig) zusprechen. 
Živina, pijan kot muha, nadelan kot muha, imeti muho, pijan kot svinja/kot prasec; пить как лошадь 'konj', напиваться//напиться, пьяный как свинья /как зюзя, муху раздавить (зашибить, задавить, убить) dobesedno 'zadaviti, ubiti muho'. Izmed predstavnikov večjih domačih živali v ruskih frazemi s pomenom 'zelo piti' nastopa samo konj, v slovenščini pa krava oz. mavra in skupno ime živina, pri čemer se sestavina krava pojavi pri označevanju tako dejanja 'piti' kot stanja 'biti pijan'. Janez Keber meni, da je zaradi velike ješčnosti in sploh velikih potreb po krmi in vodi krava zelo »primerna« za take primerjave $(1992,107 ; 2001,76)$. Tako sta tudi »primerna« živina in konj. Prvotna primerjava v frazemu pijan kot mavra je motivirana $z$ ljudskim verovanjem o mavrici, ki pije vodo. $S$ časom pa je nastala nova motivacija, povezana $\mathrm{z}$ mavro kot kravo posebne barve, tj. črna ali črnomarogasta krava (Kržišnik 1994, 94; Keber 2001, 76-77). Stanje velike pijanosti se v obeh jezikih primerja s svinjo oz. prascem. Pri tem ima ruščina še podobo prašičjega cviljenja: напиваться/напиться до поросячего визга. Po mnenju Kebra se svinji pripisuje dosti slabega, zato ni presenetljivo, da je rabljena tudi za poimenovanje pijanosti $(1992,108-109 ; 2001,83)$. Drugi živalski poimenovanji, ki sta prisotni v slovenskih frazemih s pomenom 'zelo piti', sta še žolna in žaba. Žaba je po mnenju Janeza Kebra prišla v poštev zaradi dejstva, da je vodna žival. Avtor dopušča tudi možnost, da zaradi negativne metaforične rabe za označevanje ljudi. Žolna se verjetno povezuje s pijanostjo zaradi svojega drugega poimenovanja pivka (Keber 2001, 84, 85-86; 2003, 121, 124). Jezika sta za pojem pijanosti izbrala različne živali, kar ni presenetljivo, saj lahko različni narodi isti živali pripisujejo različne lastnosti. V ruščini izstopa pri žabi kot določujoča lastnost njena hladnokrvnost (холодный как лягушка), pri kravi pa težko premikanje zaradi velikosti (неуклюжая, неповоротливая как корова). Živina se povezuje z nevljudnim, nekulturnim obnašanjem in siromašnim življenjem (вести себя, поступать как скотина; жить как скот). Pri žolni je znano, da trka po steblu drevesa. $\mathrm{Na}$ podlagi tega je prišlo do frazema долбит как дятел 'velikokrat ponavlja eno in isto'. Zanimiva je primerjava z muho. Keber razlaga, da muha že od nekdaj velja za nosilko zla in kužnih bolezni. V krščanski simboliki je podoba greha in je četrta med egiptovskimi nadlogami. Zato ni čudno, če se pojavi pri označevanju pijanosti. (1992, 109; 2001, 81). Ruščina ima tri frazeme s sestavino muha. V ruskem etimološkem slovarju frazemov najdemo naslednjo razlago: prvotna sestavina frazema муху раздавить (зашибить, задавить, убить) je izraz ubiti muho, kar je v Žargonu pri igri s kartami pomenilo "pokriti manjšo karto $\mathrm{z}$ večjo ali $\mathrm{z}$ adutom«. »Muha« je bila modna igra s kartami na začetku 19. stoletja, ki so jo posebej igrali vojaki. Po tej igri so se vračali z muho v glavi'malo pijani'. Izraz с мухой je pomenil 'z zmago, s srečo'. Drugi frazem v ruščini, ki ima sestavino тиha: под мухой је nastal kasneje pod vplivom frazemov tiра под хмельком (Slovar' russkoj frazeologii, 391-392). V Pleteršnikovem Slovensko-nemškem slovarju pod geslom muha najdemo zanimiv podatek, in sicer šesti pomen besede muha je slepa muha 'neka igra, ki se drugod imenuje slepa miš'. 


\section{naslednjih podobah:}

3.2.3 Frazemi, ki imajo $\mathrm{v}$ svojem sestavu druge sestavine, gradijo na

- $\quad$ podoba negibnosti je prisotna $\mathrm{v}$ frazemih: napiti se do mrtvega, biti nadelan do mrtvega, pijan kot bi bil ubit, na smrt pijan, pijan do nezavesti, piti na mrtvo/na žive in mrtve; напиваться//напиться в усмерть, пьян в усмерть, мертвецки пьян, напиваться//напиться, пить до бесчувствия 'do brezčutja', до потери сознания 'do nezavesti', до потери пульса 'do izgube pulza';

- $\quad$ podoba spanca oz. spanja (prim. 'stanje telesnega in duševnega počitka s popolnim ali delnim zmanjšanjem zavesti') je prisotna predvsem $v$ ruskih frazemih пить беспробудно, безпросыпно, без просыпу;

- podobo veselega stanja in razbrzdanega vedenja najdemo $v$ naslednjih frazemih: biti v rožicah, biti korajžen, быть навеселе, под куражом, в кураже;

- na absurdnih dejanjih, ki jih človek ne počenja v »normalnem« stanju, temeljijo naslednji frazemi: pijan, da samega sebe vika; pijan, da mački pravi botra; pijan, da bi žabo/žabe vikal; pijan, da ne loči meseca od sonca. V ruščini je frazem напиваться до положения риз, kar dobesedno pomeni 'napiti se do slačenja', tj. človek se tako napije, da si sleče oblačila;

- $\quad$ halucinacije, ki jih ima človek po užitju čezmerne količine alkohola, so pomenska osnova naslednjih frazemov: videti bele тіз̌i, напился до чертиков, напился до зеленого змея;

- $\quad$ na podobi neomejenosti oz. čezmernosti temeljijo naslednji frazemi: piti skozi rokav ne skozi grlo; piti, kot bi v jamo zlival, natakati se/nalivati se $z$ vinom, utopiti se $v$ vinu, хлебнуть (выпить) лишнее 'srkniti, popiti nad mero'.

\section{Sklep}

Analiza je pokazala, da je zelo malo frazemov, ki bi bili identični na vseh treh ravneh: pomenski, motivacijski in oblikovni. Več je takih frazemov, ki se razlikujejo ali na motivacijski ali na oblikovni ravni. Največjo skupino pa sestavljajo frazemi, ki imajo različne skladenjske zgradbe in gradijo na različnih podobah. Izmed sestavin, ki se najpogosteje pojavljajo $\mathrm{v}$ frazemih, prevladuje predmetna in živalska leksika, npr. živina, krava, muha, svinja, prasec, čep, klada itd. Poleg razlik najdemo $v$ obeh jezikih veliko skupnega. Upoštevajoč podobe, ki se pojavljajo $\mathrm{v}$ frazemih, lahko rečemo, da oba jezika prikazujeta pijanega človeka kot nekoga, ki se ukvarja z nekoristnim delom (npr. primerjava s premikanjem posode za vino), ki ni v »normalnem« fizičnem stanju (primerjava $z$ omahljivimi, ležečimi predmeti), ki ni v »normalnem « psihičnem stanju (absurdna dejanja in halucinacije), ki popije več kot se spodobi (npr. primerjava z živalmi). Pod besedo »normalno« je mišljeno predvsem spodobno vedenje in ravnanje, ki je $\mathrm{v}$ skladu $\mathrm{z}$ določenimi moralnimi normami in pravili neke skupnosti. Zato imajo frazemi, ki tematizirajo pijančevanje, močno negativno konotacijo. Primerjalna analiza je potrdila $v$ uvodu navedene 
trditve, da $v$ frazeologiji različnih jezikov vladajo univerzalni mehanizmi nastajanja frazemov, ki se prikazujejo predvsem na abstraktni ravni in so posledica skupnih življenjskih izkušenj, podobnih procesov mišljenja in videnja sveta.

\section{Literatura}

Apresjan, Jurij, 1995, Obraz čeloveka po dannym jazyka: popytka semantičeskogo opisanija, Voprosy jazykoznanija 1, Moskva, 37-67.

Čerdanceva, T., 1996, Idiomatika i kul'tura, Voprosy jazykoznanija 1, Moskva, 58-70.

Dobrovol'skij, D., Karaulov, 1993, Idiomatika v tezauruse jazykovoj ličnosti, Voprosy jazykoznanija 2, Moskva.

Dolenjc, B., 1999, Iz zakladnice pregovorov »Po pameti ga pijemo, da pamet ne zgubimo«, Slamnik 11, 10.

Fink-Arsovski, Željka, 2002, Poredbena frazeologija: pogled izvana i iznutra, Zagreb, Filozofski fakultet, 48-50.

Jesenšek, Vida, 2000, Protistava nemške in slovenske frazeologije - fenomen konvergentnosti, Kultura, identiteta in jezik $v$ procesih evropske integracije 2, 236-247.

Keber, Janez, 1991, Biti pijan, imeti opico, imeti mačka, piti kot krava, žaba itd., Mohorjev koledar, Celje, 107-110.

Keber, Janez, 1996, 1998, Živali v prispodobah 1, 2, Celje.

Keber, Janez, 1997, Živali v prispodobah - opica, nevšečna človekova sorodnica, Jezikoslovni zapiski 3, 127-137.

Keber, Janez, 1998, Tudi tako se lahko reče: Žlahta je strgana plahta. Dati ga na zob. Imeti pod palcem, Družinska pratika, Celje, 106-112.

Keber, Janez, 2001, Živali v izrazih s pomenom 'pijan, pijanost, (o)piti (se)', Traditiones 30, 2, 73-88.

Kržišnik, Erika, 1994, Frazeologija kot izražanje v »podobah«. Pouk slovenščine malo drugače, ur. M. Križaj Ortar, M. Bešter, E. Kržišnik, Trzin, 91-140.

Kržišnik, Erika, 2001, Frazemi s strukturo »glagol + osebni zaimek « v slovenskem jeziku. Frazeografia słowiańska, Opole, 239-248.

Solodub, J., 1982, K voprosu o sovpadenii frazeologičeskih oborotov v različnih jazykah, Voprosy jazykoznanija 2, 106-114.

Šašelj, Ivan, 1933, Kaj pripovedujejo slovenski pregovori o pijanstvu, Domoljub 47, Ljubljana.

\section{Slovarji}

Bajec, Anton, 1962, Slovenski pravopis, Ljubljana, DZS.

Bezlaj, France, 1976, 1982, 1995, Etimološki slovar slovenskega jezika, Ljubljana.

Birih, A., Mokienko, V., Stepanova, L., 1998, Slovar' russkoj frazeologii, Istorikoetimologičeskij spravočnik, Sankt Peterburg, Folio-press.

Birih, A., Mokienko, V., Stepanova, L., 2001, Slovar' frazeologičeskih sinonimov russkogo jazyka, Moskva, Astrel', AST. 
Jarancev, R., 2001, Russkaja frazeologija, Slovar'-spravočnik, Moskva, Russkij jazyk.

Keber, Janez, 2003, Frazeološki slovar slovenskega jezika, poskusni zvezek, Ljubljana, Založba ZRC, ZRC SAZU.

Pleteršnik, Maks, 1974, Slovensko-nemški slovar I, II, Ljubljana.

Slovenski pravopis, 2001, Ljubljana, Založba ZRC, ZRC SAZU.

Slovar slovenskega knjižnega jezika z Odzadnjim slovarjem slovenskega jezika in Besediščem slovenskega jezika z oblikoslovnimi podatki 1998, Elektronska izdaja na plošči CD-ROM, Ljubljana.

Snoj, Marko, 1997, Slovenski etimološki slovar, Ljubljana, Mladinska knjiga.

\section{Phrasemes Meaning 'to drink' and 'to be drunk' in Slovene and Russian Summary}

Comparative analyses of phraseology in different languages have shown that there are similarities in expressing certain topics, i.e. there are universal principles governing the formation of phrasemes. These principles originate in common experiences in life of nations and their similar processes of thinking and perception of the world. Universal principles are typical of Russian and Slovene phraseology as well. This article discusses phrasemes meaning 'to drink' and 'to be drunk'. Similarities between these phrasemes are found especially at an abstract level.

Considering the imagery used in these phrasemes it can be said that both languages describe a drunken person as somebody who is doing something useless (e.g. comparison with moving wine vessels: segati po steklenici, ne braniti se kozarca, prazniti//izpraznjevati kozarce, (pridno) nagibati kozarec, прикладываться// приложиться к бутылке, пропускать по рюмочке, придерживаться рюмочки/ стаканчика, etc.), as somebody who is not in "normal" physical condition (comparison with unstable, lying objects: pijan kot metla/kot klada/kot batina, пьян как чурбан, пьян как колода, etc.), as somebody who is not in "normal" mental state (absurd actions and hallucinations: pijan, da samega sebe vika; pijan, da mački pravi botra, videti bele miši, напился до чертиков, напился до зеленого змея, etc.), as somebody who drinks more than what is considered to be decent (e.g. comparison with animals: piti, pijan kot (božja) mavra/kot krava, pijan kot svinja/ kot prasec; пить как лошадь, напиваться//напиться, пъяный как свинья, etc.). Here "normal" is mainly used to denote decent behaviour as perceived in accordance with certain moral standards and rules of a given society. Therefore there is a strong negative connotation in phrasemes denoting (excessive) drinking. According to the results of author's analysis the most frequent components in phrasemes describing (excessive) drinking are lexemes that denote objects and animals, e.g. čep 'cork', klada 'log', živina 'cattle', krava 'cow', muha 'fly', svinja 'pig', etc. 